\title{
Labour Market Dualism in the Lewis Model: Reply
}

\author{
Gary S. Fields ${ }^{1}$
}

Cornell University

Richard Brown (2006) has written that the interpretation of the 1954 Lewis model that I presented in Fields (2004) is 'flawed for a number of reasons' and 'Fields's appreciation of the contribution of the Lewis model to understanding the process of wage determination in developing economies is therefore misplaced'. In this reply, I explain why I think the flaws are not mine but Brown's.

Before proceeding, I wish to point out that the conference at which my paper was presented and the issue of The Manchester School in which my paper was published were entitled 'The Lewis Model after Fifty Years'. Accordingly, my paper and this reply focus on Lewis's original 1954 paper.

\section{The Essence of Labour Market Dualism}

My paper was entitled 'Dualism in the Labor Market: a Perspective on the Lewis Model after Half a Century'. As in my paper, I shall use the formal/informal terminology in this reply.

I began my paper by explaining that the essence of labour market dualism is that 'different wages are paid to comparable workers'. The quotations from pp. 148-149 of Lewis (1954) in Brown's comment state exactly this. Given these quotes, I am mystified how Brown could write, 'Fields's argument that "At the core of the Lewis model is labour market dualism" (2004, p. 724) is incorrect in relation to the original (1954) statement of his model'.

Brown continues, 'Although the labour force in the original Lewis model is divided between the two sectors of the economy, there was no segmentation or labour market dualism in terms of restrictions on the entry of labour into the formal from the informal sector'. This is nonsense. Obviously, it is not the case in the Lewis model that all who work in the traditional sector and who would like to work in the modern sector are able to do so. The reason is obvious: modern sector labour demand is insufficient to employ all who would like to work in that sector at that wage. It is precisely that fact that led Lewis to analyse economic development with unlimited supplies of labour. (By the way, 'unlimited supply of labour' to the formal sector is a perfectly legitimate expression. 'Perfectly elastic supply of labour' is not.)

In the remainder of this reply, I first explain my interpretation of how Lewis (1954) understood wage determination in the formal sector, wage determination in the informal sector and the dynamics of wage determination. The reason I say 'my interpretation' is that Lewis was unclear on two major points, with the consequence that readers can and do take away different messages from Lewis.

\section{Wage Determination in the Formal Sector At Any Given Time}

In Fields (2004), I accepted Lewis's judgement that wages in the formal sector are not set neoclassically by formal sector labour supply and labour demand. Of course, to say how wages are

\footnotetext{
${ }^{1}$ I am grateful to Gustav Ranis for many helpful discussions during the preparation of this reply.
} 
not determined is not to say how wages are determined. On this, we confront a problem with Lewis (1954) and his later writings: Lewis's own ambiguity over how formal sector wages are determined. There are two mutually contradictory mechanisms at work in Lewis's papers, a confusion repeated in Brown's comment.

One mechanism, the one that reflects my own reading of Lewis and of the subsequent elaboration of his model by Fei and Ranis (1964), is that the formal sector wage is set by a combination of institutional forces that might include unions, minimum wages and public sector pay policy. Brown and I are in full agreement on this interpretation. Indeed, Brown writes that, for Lewis, the critical issue is that 'the modern sector labour market, with an institutionally fixed real wage, is faced with an unlimited labour supply from the traditional sector'.

Lewis, however, put forward a second mechanism: 'Anything which raises the productivity of the subsistence sector (average per person) will raise real wages in the capitalist sector'. This statement is repeated by Brown. Unfortunately, this statement of Lewis's directly contradicts the other statement of his quoted in the previous paragraph.

Why is this a contradiction? Either (i) the wage in the formal sector is institutionally fixed, meaning that it is a function only of institutions and not other things, or (ii) the wage in the formal sector is a function of subsistence sector productivity. It cannot be both.

I continue to understand Lewis to have meant (i), not (ii), although I recognize that, because Lewis was ambiguous, others might understand it differently.

\section{Wage Determinants in the Informal Sector At Any Given Time}

In Fields (2004), I accepted Lewis's judgement that the wage in the informal sector is set in relation to average informal sector productivity. At the same time, I called attention to a 'troublesome feature' of Lewis's (1954) model: whether what Lewis called the 'subsistence wage' in the informal sector was a constant low wage or whether it varied (inversely) with the number of people in the sector. I opined, 'From my reading of Lewis, there can be little doubt that he regarded production in the informal sector as subject to diminishing returns, a point that is explicit in Fei and Ranis's amplification of the Lewis model'. I continued, 'Thus, when economic growth takes place and workers are drawn out of the informal sector into the formal sector, those who remain in the informal sector each receive a higher income than before'.

What, then, determines wages in the informal sector? For me, as for Lewis (and also Fei and Ranis as well as Sen (1967)), wages in the informal sector are a function of the average product of labour in the informal sector, which in turn is caused by employment in the formal sector. Therefore, it is absolutely beyond me how Brown could characterize my position as being that wages in the informal sector are determined independently of conditions in the formal sector.

\section{How Does Economic Growth Affect Wages and Employment in the Two Sectors?}

To sum up the preceding: the real wage in the modern sector and the utility of a worker employed in that sector are higher than in the traditional sector. As long as the real wage differential remains sufficiently large, the formal sector faces an unlimited supply of labour, meaning that employers there can hire more workers if they want to without raising the wage. Suppose that employers do indeed hire more labour. As labour is withdrawn from the informal sector, the average productivity of labour in that sector will rise. Assuming that workers in the informal sector are paid their average product, informal sector wages will rise accordingly. 
Now comes the key question: as labour is withdrawn from the informal sector and the wage in that sector rises, does the increase in the informal sector wage cause the formal sector wage to rise, for example, because the unions are able to negotiate higher wages or because the government chooses to raise the minimum wage? From my reading of Lewis (Fig. 3 on p. 152, where the formal sector wage is constant) and Fei and Ranis (p. 204: 'We assume that the institutionally determined wage level AS continues to prevail as long as some disguised unemployed workers remain in agriculture'], I would think that the formal sector wage does not rise as a consequence of increased modern sector employment.

To the contrary, suppose that the formal sector wage did rise in response to an increase in the informal sector wage-in particular, that the 30 per cent differential assumed by Lewis continued to persist. If this were the case, things would look very different. For one thing, the w line in Fig. 3 of Lewis (1954) would be upward-sloping, not horizontal. Second, and more importantly, because the wage in the formal sector remains sufficiently higher than the wage in the informal sector, 'everybody' would always want to work in the formal sector and therefore there would never be a Lewis-Fei-Ranis turning point. Lewis, of course, believed that the unlimited supply of labour would end, which is why I think that, if faced with this contradiction, Lewis would have opted for institutional wage setting in the formal sector.

I therefore cannot accept Brown's claim that 'To conceptualize this as a segmented or dual labour market is incorrect'. It is Brown, not I, who is incorrect.

\section{Where Should We Go From Here?}

In Fields (1975), I developed a model with three types of jobs-urban formal sector employment, urban informal sector employment and rural agricultural sector employment-as well as unemployment. Later, Lewis (1979) also distinguished between the urban formal sector and the urban informal sector. In my view, such three- and four-state models are more realistic and should serve as the foundation for current efforts to understand the role of labour markets in the process of economic development.

As an attempt to aid others in understanding the major options for such modelling, I wrote a paper (Fields, 2005) reviewing the major multisector labour market models found in the literature today. These models take care in specifying what goes on within each sector and how the sectors are related to one another. The single most important lesson to emerge from these models is that what goes on within one labour market can only be understood by understanding what is going on in all labour markets.

In the last 50 years, mainstream economics has moved beyond the kinds of purely verbal expositions of the types used by Lewis and Brown. The major advantage of modern algebraic formulations is that, when they are done well, they make explicit how each component of the model is supposed to work. An algebraic formulation of the Lewis model would have left no doubt about whether wages in the formal sector are determined by formal sector labour market institutions or whether they are determined as a function of average labour productivity in the informal sector. Similarly, an algebraic formulation would have left no doubt about whether wages in the informal sector are constant or whether they rise as workers leave the informal sector to take up jobs in the expanding formal sector. Sadly, without Arthur Lewis alive to ask, we cannot possibly know what his answers to these ambiguities would have been.

I see little point in continuing to debate what Lewis would have said. The challenge for us today is to move forward as rigorously and comprehensively as we can, based on our own judgements of what the right features of labour market dualism should be today. 


\section{References:}

Brown, R. P. C. (2006). 'On Labour Market Dualism in the Lewis Model: a Comment', The Manchester School, Vol. 74, No. 3, pp. 350-354.

Fei, J. C. H. and Ranis, G. (1964). Development of the Labor Surplus Economy, Homewood, IL, Irwin.

Fields, G. S. (1975). 'Rural-Urban Migration, Urban Unemployment and Underemployment, and Job Search Activity in LDC's', Journal of Development Economics, Vol. 2, pp. 165-188.

Fields, G. S. (2004). 'Dualism in the Labor Market: a Perspective on the Lewis Model after Half a Century', The Manchester School, Vol. 72, pp. 724-735.

Fields, G. S. (2005). 'A Guide to Multisector Labor Market Models', Social Protection Discussion Paper 0505, World Bank.

Lewis, W. A. (1954). 'Economic Development with Unlimited Supplies of Labour', The Manchester School, Vol. 22, pp. 139191.

Lewis, W. A. (1979). 'The Dual Economy Revisited', The Manchester School, Vol. 47, pp. 211-229.

Sen, A. K. (1967). 'Review of J. C. H. Fei and G. Ranis, Development of the Labor Surplus Economy: Theory and Policy', The Economic Journal, Vol. 77, pp. 346-349. 